\title{
4PENGARUH DOSIS PUPUK BOKASHI SAPI DAN PENGGUNAAN JENIS MULSA TERHADAP PRODUKSI TANAMAN KACANG PANJANG (Vigna sinensis L.) VARIETAS PERTIWI
}

\author{
Oleh : \\ Muhammad Rofiq \\ Pamuji Setyo Utomo \\ Tarwa Mustofa \\ Email: ahmadrofiq35@gmail.com \\ Program Studi Agroteknologi, Fakultas Pertanian, Universitas Islam Kadiri
}

\begin{abstract}
ABSTRAK
Tanaman kacang panjang (Vigna Sinensis L.) merupakan salah satu komoditas sayuran yang sangat potensial untuk dikembangkan, karena mempunyai nilai ekonomi yang cukup tinggi. Kacang panjang dapat dikonsumsi dalam bentuk segar maupun diolah menjadi sayur. Dalam upaya peningkatan gizi masyarakat, kacang panjang penting sebagai sumber vitamin dan mineral. Menurut Haryanto (2003), biji kacang panjang mengandung karbohidrat $(70,00 \%)$, protein $(17,30 \%)$, lemak $(1,50 \%)$ dan air $(12,20 \%)$, sehingga komoditi ini juga merupakan sumber protein nabati. Selain penting sebagai sayuran dan sumber protein nabati,tanaman ini juga dapat menyuburkan tanah. Pada akar kacang panjang terdapat bintil-bintil akar yang berisi bakteri Rhizobium sp. yang dapat menambah nitrogen bebas dari udara dan merubahnya menjadi bentuk yang dibutuhkan tanaman. Penelitian ini bertujuan Untuk mengetahui interaksi antara pemberian pupuk bokashi sapi dan penggunaan macam jenis mulsa terhadap pertumbuhan dan produksi tanaman kacang panjang varietas pertiwi.Penelitian dilaksanakan pada bulan Januari - Maret, dengan menggunakan rancangan perlakuan faktorial dan rancangan lingkungan acak kelompok (RAK) yang terdiri dari dua Faktor, masing-masing faktor terdiri dari tiga kelompok yaitu dengan dosis pupuk bokashi 6 ton/ha, dosis pupuk bokashi 12 ton/ha, dosis pupuk bokashi 18 ton/ha. Faktor kedua terdiri dari jenis mulsa, yaitu mulsa jerami, mulsa perak-perak, dan mulsa hitam-perak, dan dari kedua faktor tersebut dapat dikombinasikan. Pada Penelitian ini Terjadi interaksi sangat nyata antara perlakuan dosis pupuk bokashi dan macam jenis mulsa pada variabel pengamatan : panjang tanaman umur $42 \mathrm{hst}$, dan terjadi interaksi nyata pada varisabel diameter batang umur 28 dan 42 hst. Terjadi perbedaan pada perlakuan tunggal, yaitu perlakuan mulsa pada variabel jumlah helai daun pada umur 14, 28, dan 42 hst. Tidak terjadi interaksi pada variabel berat polong, jumlah polong, dan panjang polong pada akumulasi panen I - V. Akan tetapi ada perbedaan nyata pada perlakuan tunggal, yaitu perlakuan mulsa pada variable berat dan jumlah polong per tanaman pada akumulasi panen I-V.
\end{abstract}

Kata Kunci : Pupuk Bokashi Sapi, Jenis Mulsa, Kacang Panjang.

ABSTRACT
Long bean (Vigna Sinensis L.) is one of the vegetable commodities that has the potential to be
developed, because it has a fairly high economic value. Long beans can be consumed fresh or processed into
vegetables. In an effort to improve people's nutrition, long beans are important as a source of vitamins and
minerals. According to Haryanto (2003), long bean seeds contain carbohydrates (70.00\%), protein
PENGARUH DOSIS PUPUK BOKASHI SAPI MUHAMMAD ROFIQ, PAMUJI SETYO UTOMO
DAN PENGGUNAAN JENIS MULSA
TERHADAP PRODUKSI TANAMAN KACANG
PANJANG (Vigna sinensis L.) VARIETAS
PERTIWI


(17.30\%), fat (1.50\%) and water (12.20\%), so this commodity is also a source of vegetable protein. . Besides being important as a vegetable and a source of vegetable protein, this plant can also fertilize the soil. On the roots of long beans there are root nodules containing the bacterium Rhizobium sp. which can add free nitrogen from the air and convert it into the form that plants need. This study aims to determine the interaction between the application of cow bokashi fertilizer and the use of various types of mulch on the growth and production of long bean varieties. two factors, each factor consists of three groups, namely with a dose of 6 tons of bokashi fertilizer/ha, a dose of 12 tons of bokashi fertilizer/ha, and a dose of 18 tons of bokashi fertilizer. The second factor consisted of the type of mulch, namely straw mulch, silver-silver mulch, and black-silver mulch, and the two factors could be combined. In this study, there was a very significant interaction between the treatment dose of bokashi fertilizer and the types of mulch on the observation variables: plant length at 42 days after planting, and a significant interaction occurred in stem diameter variables at 28 and 42 days after planting. There was a difference in the single treatment, namely the mulch treatment on the variable number of leaves at the age of 14, 28, and 42 days after planting. There was no interaction on the variables of pod weight, number of pods, and pod length in the accumulation of harvests $I-V$. However, there was a significant difference in the single treatment, namely the mulch treatment on the variable weight and the number of pods per plant on the accumulated harvests $I-V$.

Keywords: Bokashi Cow Fertilizer, Mulch Type, Long Beans. 


\section{PENDAHULUAN}

Tanaman kacang panjang (Vigna Sinensis L.) merupakan salah satu komoditas sayuran yang sangat potensial untuk dikembangkan, karena mempunyai nilai ekonomi yang cukup tinggi. Kacang panjang dapat dikonsumsi dalam bentuk segar maupun diolah menjadi sayur. Dalam upaya peningkatan gizi masyarakat, kacang panjang penting sebagai sumber vitamin dan mineral. Menurut Haryanto (2003), biji kacang panjang mengandung karbohidrat $(70,00 \%)$, protein $(17,30 \%)$, lemak $(1,50 \%)$ dan air (12,20\%), sehingga komoditi ini juga merupakan sumber protein nabati. Selain penting sebagai sayuran dan sumber protein nabati, tanaman ini juga dapat menyuburkan tanah. Pada akar kacang panjang terdapat bintil-bintil akar yang berisi bakteri Rhizobium sp. yang dapat menambah nitrogen bebas dari udara dan merubahnya menjadi bentuk yang dibutuhkan tanaman.

Banyak permasalahan yang dihadapi oleh petani kacang panjang yang menyebabkan produksi kacang panjang menurun. Penyebab menurunnya produksi kacang panjang antara lain iklim, bibit unggul, pupuk dan hama penyakit. Pemupukan merupakan aspek penting dalam budidaya kacang panjang yang dapat meningkatkan produksi panen kacang panjang. Oleh karena itu usaha untuk meningkatkan produktivitas kacang panjang perlu terus dilakukan melalui upaya budidaya tanaman yang tepat yaitu termasuk dalam aspek pemeliharaannya yaitu pemupukan.

Mulsa adalah bahan untuk menutup tanah sehingga kelembaban dan suhu tanah sebagai media tanaman terjaga kestabilannya. Mulsa juga berfungsi menekan pertumbuhan gulma sehingga tanaman akan tumbuh lebih baik (Erika, 2014). Gulma yang tumbuh di sekitar tanaman akan sangat mengganggu tanaman kacang panjang, karena gulma mengeluarkan zat aleopati dan menghambat pertumbuhan tanaman kacang panjang. Selain itu mulsa terbukti dapat meningkatkan hasil dari produksi tanaman hortikultura lainnya seperti kentang dan wortel (Kharisma, 2016)

\section{METODELOGI PENELITIAN}

\section{Waktu dan Tempat}

Penelitian ini dilaksanakan pada bulan Januari 2020 hingga Maret 2020 di lahan sawah dengan jenis tanah Regosol dengan $\mathrm{pH}$ tanah 6 , suhu udara $23^{\circ} \mathrm{C}-30^{\circ} \mathrm{C}$, Curah hujan rata-rata pertahun sebesar 130-150 mm dengan kelembapan nisbi 7486\%. Bertempat di Desa Tambak Rejo, Kecamatan Gurah, Kabupaten Kediri, dengan ketinggian $67 \mathrm{mdpl}$

\section{Alat dan Bahan}

Alat yang digunakan pada penelitian ini adalah cangkul, sabit, meteran, kamera, lanjaran, timbangan, timba, bajak, jangka sorong, plong mulsa, gembor, ATK.

\begin{tabular}{|c|c|}
\hline PENGARUH DOSIS PUPUK BOKASHI SAPI & MUHAMMAD ROFIQ, PAMUJI SETYO UTOMO \\
\hline PENGGUNAAN & dan TARWA MUSTOFA \\
\hline \multicolumn{2}{|l|}{ TERHADAP PRODUKSI TANAMAN KACANG } \\
\hline $\begin{array}{l}\text { PANJANG (Vigna sinensis } \\
\text { PERTIWI }\end{array}$ & \\
\hline
\end{tabular}


Bahan yang digunakan pada penelitian ini adalah pupuk bokashi sapi, benih kacang panjang varietas pertiwi, mulsa jerami, mulsa perak, mulsa hitam perak, plat label perlakuan, lanjaran, pupuk susulan, pestisida.

\section{Metode Penelitian}

Penelitian menggunakan Rancangan lingkungan, Rancangan Acak Kelompok (RAK) yang terdiri dari 3 dosis, dan rancangan perlakuan, setiap factor memiliki 3 ulangan. Faktor pertama adalah Dosis Pupuk Bokashi $(B)=$ B1: 6 ton/ha, B2: 12 ton/ha, B3: 18 ton/ha. Faktor kedua adalah Jenis Mulsa $(\mathrm{M})=$ M1: Jerami, M2: Mulsa Perak, M3: Mulsa Hitam Perak. Dari kedua factor tersebut, maka diperoleh 9 kombinasi perlakuan

\section{Analisis Data}

Data yang diperoleh dari hasil pengamatan pada masing - masing uji $\mathrm{F}$ dengan metode variabel dimasukkan pada tabel untuk dilakukan diuji F dengan metode Sidik Ragam (ANOVA). Apabila kombinasi antar perlakuan terjadi interaksi, maka dilakukan uji perbandingan dengan metode uji DMRT (Duncan) 5\% dengan membandingkan nilai rata - rata kombinasi perlakuan untuk mengetahui nilai mana yang berbeda nyata maupun sama dan jika tidak ada interaksi, maka dilanjutkan dengan metode uji BNT (Beda Nyata Terkecil) 5\%.

\section{HASIL DAN PEMBAHASAN}

\section{Panjang Tanaman}

Hasil analisa ragam menunjukan bahwa kombinasi perlakuan dosis pupuk bokashi dan macam penggunaan jenis mulsa pada parameter panjang tanaman terjadi interaksi sangat nyata pada umur 42 hst, dan berbeda sangat nyata pada perlakuan tunggal macam varietas pada umur 28 hst.

Tabe 1. Rata-rata panjang tanaman $(\mathrm{cm})$ akibat pengaruh kombinnasi perlakuan dosis pupuk bokashi dan macam jenis mulsa pada umur 42 hst.

\begin{tabular}{cc}
\hline Kombinasi & Rata-Rata Panjang Tanaman \\
\hline B1M1 & $288,00 \mathrm{a}$ \\
B1M2 & $303,87 \mathrm{~b}$ \\
B1M3 & $328,73 \mathrm{c}$ \\
B2M1 & $370,73 \mathrm{e}$ \\
B2M2 & $351,07 \mathrm{~d}$ \\
B2M3 & $443,07 \mathrm{f}$ \\
B3M1 & $334,60 \mathrm{c}$ \\
B3M2 & $479,47 \mathrm{~g}$ \\
B3M3 & $372,27 \mathrm{e}$ \\
\hline
\end{tabular}

Keterangan: Angka-angka yang diikuti dengan huruf yang sama pada kolom perlakuan yang sama menunjukan tidak berbeda nyata pengaruhnya dengan uji DMRT pada taraf 5\%. 
Berdasarkan uji DMRT 5\%, rata-rata tertinggi panjang tanaman dihasilkan dari perlakuan kombinasi B3M2 dosis pupuk bokashi 18 ton/ha dengan mulsa perakperak $(479,47 \mathrm{~cm})$ pada usia 42 hst. Dan berbeda nyata dengan perlakuan yang lain.

Hal tersebut terjadi karena kombinasi B3M2 menggunakan dosis pupuk paling tinggi yaitu 18 ton/ha, sehingga kebutuhan hara pada tanaman dapat terpenuhi, dengan dikombinasi menggunakan perlakuan mulsa menyebabkan tanaman semakin baik pertumbuhannya, karena mulsa perak-perak selain menjaga kondisi iklim mikro tanah menjadi lebih baik, juga memantulkan cahaya matahari dari bawah, sehingga tanaman dapat berfotosintesis dengan lebih baik dan terhindar dari serangan hama.

Didukung dengan pendapat Lingga dan Marsono (2008) bahwa pupuk organik memiliki kandungan unsur hara yang lengkap dalam jumlah yang sedikit, meski kadarnya rendah tetapi mampu memperbaiki kondisi. Hal tersebut juga didukung oleh Lamont dan Orzolek di penelitian Kharisma (2016) melaporkan bahwa dari beberapa penelitian yang dilakukan pada berbagai sayuran menunjukkan respon yang berbeda-beda terhadap warna mulsa tertentu. Warna mulsa plastik menentukan energi radiasi yang diterima, mempengaruhi iklim mikro di sekitar tanaman, dan secara spesifik warna mulsa plastik menentukan suhu udara di permukaan mulsa dan suhu tanah di bawah mulsa.

\section{Jumlah Daun}

Hasil analisa sidik ragam menunjukan pengaruh pemberian pupuk bokashi dan penggunaan macam jenis mulsa tidak menunjukkan interaksi pada parameter jumlah daun (helai), akan tetapi menunnjukkan berbeda sangat nyata pada perlakuan tunggal pada umur 14, 28, dan 42 hst.

Tabel 2. Rata-rata jumlah daun tanaman kacang panjang akibat pengaruh pemberian dosis pupuk bokashi dan penggunaam jenis mulsa pada tanaman kacang panjang.

\begin{tabular}{cccc}
\hline \multirow{2}{*}{ Perlakuan Tunggal } & \multicolumn{3}{c}{ Rata-Rata } \\
\cline { 2 - 4 } & $\mathbf{1 4}$ hst & $\mathbf{2 8}$ hst & 42 hst \\
\hline B1 & 6,96 & 25,47 & 64,62 \\
B2 & 6,96 & 25,53 & 66,82 \\
B3 & 7,31 & 25,87 & 67,31 \\
Bnt 5\% & 1,32 & 2,95 & 4,08 \\
M1 & $6,07 \mathrm{a}$ & $23,27 \mathrm{a}$ & $61,22 \mathrm{a}$ \\
M2 & $7,18 \mathrm{ab}$ & $26,31 \mathrm{~b}$ & $70,33 \mathrm{~b}$ \\
M3 & $7,98 \mathrm{~b}$ & $27,29 \mathrm{~b}$ & $67,2 \mathrm{~b}$ \\
\hline
\end{tabular}

Keterangan : Nilai yang diikuti dengan huruf yang sama pada baris dan kolom, tidak berbeda nyata pengaruhnya pada uji BNT pada taraf 5\%.

Berdasarkan uji BNT 5\% menunjukkan bahwa perlakuan dosis pupuk bokashi tidak berberbeda nyata pada semua umur tanaman. Akan tetapi berbeda dengan pengaruh penggunaan macam jenis mulsa, menunjukkan perbedaan sangat nyata disetiap umur tanaman. Pada saat umur 14 hst, jumlah helai daun paling banyak pada perlakuan mulsa hitam perak (M3) dengan jumlah helai 7,98, jumlah itu tidak berbeda

\begin{tabular}{|c|c|}
\hline PENGARUH DOSIS PUPUK BOKASHI SAPI & MUHAMMAD ROFIQ, PAMUJI SETYO UTOMO \\
\hline PENGGUNAAN & dan TARWA MUSTOFA \\
\hline \multicolumn{2}{|l|}{ TERHADAP PRODUKSI TANAMAN KACANG } \\
\hline $\begin{array}{l}\text { PANJANG (Vigna sinensis } \\
\text { PERTIWI }\end{array}$ & \\
\hline
\end{tabular}


nyata dengan perlakuan mulsa perak-perak (M2) dengan jumlah helai 7,18, dan mulsa jerami (M1) dengan jumlah helai 6,07. Pada saat umur 28 hst jumlah helai paling banyak pada perlakuan mulsa hitam perak ,akan tetapi tidak berbeda nyata dengan mulsa perak-perak, dan berbeda nyata dengan mulsa jerami. Pada tanaman umur 42 hst, jumlah helai terbanyak pada perlakuan mulsa perak-perak dengan jumlah helai 70,33, namun tidak berbeda nyata dengan perlakuan mulsa hitam perak dengan jumlah helai 67,20, dan berbeda nyata dengam perlakuan mulsa jerami dengan jumlah helai 61,22 .

Pada penelitian ini perlakuan mulsa menunjukkan berbeda sangat nyata, karena mulsa plastik lebih rapat daripada mulsa jerami. Sehingga, dapat melindungi permukaan tanah di sekitar tanaman pada saat hujan. Terlindunginya tanah dari terik matahari langsung menyebabkan berkurangnya penguapan yang terjadi di sekitar tanaman, sehingga tanah tidak cepat kehilangan kelembapan. Dan terlindunginya tanah dari hujan, menyebabkan unsur hara tidak mudah tercuci, sehingga tanah tidak mudah kehilangan unsur haranya. Mulsa plastik juga lebih baik dalam menjaga kondisi iklim mikro tanaman.

\section{Diameter Batang}

Hasil analisa sidik ragam menunujukan bahwa kombinasi macam dosis pupuk bokashi dan macam jenis mulsa terjadi interaksi nyata pada parameter diameter batang umur 28 hari setelah tanam, dan 42 hari setelah tanam.

Tabel 3. Rata-rata diameter batang $(\mathrm{mm})$ akibat pengaruh kombinasi perlakuan dosis pupuk bokashi dan macam jenis mulsa pada umur 28 hst, dan 42 hst.

\begin{tabular}{ccc}
\hline \multirow{2}{*}{ Kombinasi } & \multicolumn{2}{c}{ Rata-Rata } \\
\cline { 2 - 3 } & $\mathbf{2 8}$ & $\mathbf{4 2}$ \\
\hline B1M1 & $4,29 \mathrm{ab}$ & $5,05 \mathrm{~b}$ \\
B1M2 & $4,21 \mathrm{ab}$ & $5,15 \mathrm{c}$ \\
B1M3 & $4,91 \mathrm{~d}$ & $5,21 \mathrm{c}$ \\
B2M1 & $4,32 \mathrm{abc}$ & $4,74 \mathrm{a}$ \\
B2M2 & $4,73 \mathrm{bcd}$ & $5,15 \mathrm{c}$ \\
B2M3 & $4,51 \mathrm{bcd}$ & $5,49 \mathrm{~cd}$ \\
B3M1 & $3,92 \mathrm{a}$ & $4,79 \mathrm{ab}$ \\
B3M2 & $4,85 \mathrm{~cd}$ & $5,14 \mathrm{c}$ \\
B3M3 & $4,91 \mathrm{~d}$ & $5,65 \mathrm{~d}$ \\
\hline
\end{tabular}

Keterangan: Angka-angka yang diikuti dengan huruf yang sama pada kolom perlakuan yang sama menunjukan tidak berbeda nyata pengaruhnya dengan uji DMRT pada taraf 5\%.

Berdasarkan uji DMRT 5\% rata-rata diameter batang tertinggi pada umur 28 hst dihasilkan oleh perlakuan kombinasi B3M3 dosis pupuk bokashi 18 ton/ha, dan mulsa hitam-perak $(4,91 \mathrm{~mm})$. Akan tetapi kobinasi tersebut tidak berbeda nyata dengan kombinasi B1M3 dosis pupuk 6 ton/ha dengan mulsa hitam-perak, B3M2 dosis pupuk 18 ton/ha dengan mulsa perak-perak, B2M2 dosis pupuk 12 ton/ha dengan mulsa perak-perak, B2M3 dosis pupuk 12 ton/ha dengan mulsa hitam-perak, B2M1 dosis pupuk 12 ton/ha dengan mulsa jerami, B1M1 dosis pupuk 6 ton/ha

\begin{tabular}{|c|c|}
\hline PENGARUH DOSIS PUPUK BOKASHI SAPI & MUHAMMAD ROFIQ, PAMUJI SETYO UTOMO \\
\hline PENGGUNAAN & dan TARWA MUSTOFA \\
\hline \multicolumn{2}{|l|}{ TERHADAP PRODUKSI TANAMAN KACANG } \\
\hline $\begin{array}{l}\text { PANJANG (Vigna sinensis } \\
\text { PERTIWI }\end{array}$ & \\
\hline
\end{tabular}


dengan mulsa jerami, B1M2 dosis pupuk 6 ton/ha dengan mulsa perak-perak. Dan nerbeda nyata dengan perlakuan B3M1 dosis pupuk 18 ton/ha dengan mulsa jerami.

Rata-rata tertinggi pada umur 42 hari setelah tanam dihasilakn oleh perlakuan kombinasi B3M3 dosis pupuk 18 ton/ha dan mulsa hitam-perak (5,56 mm). Namun kombinasi ini tidak berbeda nyata dengan kombinasi B2M3 dosis pupuk 12 ton/ha dengan mulsa hitam-perak, B2M2 dosis pupuk 12 ton/ha dengan mulsa perak-perak, B1M3 dosis pupuk 6 ton/ha dengan mulsa hitam-perak, B1M2 dosis pupuk 6 ton/ha dengan mulsa perak-perak.

Dalam tabel dapat dilihat bahwa kombinasi tertinggi di kedua umur tanaman (28 hst dan 42 hst) adalah kombinasi pupuk bokashi 18 ton/ha dengan mulsa hitamperak. Hal ini disebabkan tanaman mendapat cukup unsur hara dan mulsa hitam perak dapat mencegah tanah tergenang oleh air, berbeda dengan mulsa jerami yang tidak dapat melindungi dari jatuhnya air hujan secara langsung ke tanah yang dapat menyebabkan air menggenang. Air yang menggenang sangat tidak baik untuk aerasi tanah, dan air tersebut dapat menyebabkan pencucian unsur hara yang tidak baik untuk tanaman.

\section{Berat Polong Per Tanaman}

Hasil analisia ragam menunjukan bahwa bahwa tidak ada interaksi antara kombinasi perlakuan dosis pupuk bokashi dan macam jenis mulsa pada parameter berat polong per tanaman pada akumulasi panen pertama sampai kelima. Tetapi ada berbeda nyata di perlakuan macam jenis mulsa.

Tabel 4. Rata-rata berat polong tanaman kacang panjang (gr) akibat pengaruh pemberian dosis pupuk bokashi dan macam varietas kacang panjang.

\begin{tabular}{cc}
\hline Perlakuan Tunggal & Rata - rata berat per tanaman $\mathbf{~ g r )}$ \\
\hline B1 & 1.433 \\
B2 & 1.594 \\
B3 & 1.472 \\
BNT 5\% & 770 \\
M1 & $1139 \mathrm{a}$ \\
M2 & $1444 \mathrm{ab}$ \\
M3 & $1917 \mathrm{~b}$ \\
\hline
\end{tabular}

Keterangan: Nilai yang diikuti dengan huruf yang sama pada baris dan kolom yang sama, tidak berbeda nyata pengaruhnya pada uji BNT pada taraf $5 \%$.

Berdasarkan uji BNT 5\% menunjukkan bahwa perlakuan dosis pupuk bokashi tidak berberbeda nyata pada akumulsi panen pertama sampai kelima. Akan tetapi berbeda dengan pengaruh penggunaan macam jenis mulsa, menunjukkan perbedaan nyata. Pada akumulasi panen pertama paling banyak pada perlakuan mulsa hitam perak (M3) dengan berat polong 1.917 gr per tanaman. Perlakuan mulsa hitam-perak tidak berbeda nyata dengan perlakuan mulsa perak-perak (M2) dengan berat polong pertanaman 1.444 gr. Dan terjadi perbedaan nyata dengan perlakuan mulsa jerami (M1) dengan berat polong per tanaman 1.139 gr. 
Hal ini disebabkan oleh kandungan unsur hara yang sedikit di dalam pupuk bokashi. Sehingga tidak terlihat perbedaan yang signifikan antara perlakuan pupuk bokashi. Dan penggunaan mulsa plastik yang dapat memantulkan radiasi matahari, yang menyebabkan suhu tanah menjadi lebih rendah. Suhu rendah dapat mengurangi laju respirasi akar, yang menyebabkan akar menjadi lebih kuat dan sehat.

\section{Jumlah Polong Per Tanaman}

Hasil analisia ragam menunjukan bahwa bahwa tidak ada interaksi antara kombinasi perlakuan dosis pupuk bokashi dan macam jenis mulsa pada parameter jumlah polong pada akumulasi panen pertama sampai kelima. Tetapi ada berbeda nyata di perlakuan macam jenis mulsa.

Tabel 5. Rata-rata jumlah polong tanaman kacang panjang akibat pengaruh pemberian dosis pupuk bokashi dan macam varietas kacang panjang.

\begin{tabular}{cc}
\hline Perlakuan Tunggal & Rata - rata \\
\hline B1 & 45,67 \\
B2 & 51,67 \\
B3 & 48,22 \\
BNT 5\% & 19,71 \\
M1 & $39,33 \mathrm{a}$ \\
M2 & $47,11 \mathrm{ab}$ \\
M3 & $59,11 \mathrm{~b}$ \\
\hline
\end{tabular}

Keterangan: Nilai yang diikuti dengan huruf yang sama pada baris dan kolom yang sama, tidak berbeda nyata pengaruhnya pada uji BNT pada taraf $5 \%$.

Berdasarkan uji BNT 5\% menunjukan bahwa dosis pupuk bokashi tidak berbeda nyata pada variable jumlah polong. Akan tetapi berbeda nyata di perlakuan jenis mulsa. Mulsa jerami menghasilkan 39,71 buah. Tidak berbeda nyata dengan mulsa perak-perak yang mengahsilkan 47,11 buah. Dan berbeda nyata dengan mulsa hitam perak yang menghasilkan 59,11 buah.

Hal ini terjadi karena sifat dari pupuk organik yang memiliki kandungan unsur hara yang sedikit dan perlu waktu yang lama untuk dapat di serap oleh tanaman. Kandungan nutrisi dalam tanah dan ketersediaanya yang lambat, maka penyediaan nutrisi dari pupuk organik tidak cukup dalam menyediakan kebutuhannya bagi tanaman. Penggunaan jenis mulsa berbeda nyata pada variable jumlah polong pertanaman karena penggunaan mulsa hitam perak sangat efektif untuk menjaga iklim mikro tanaman,dan mencegah pertumbuhan gulma. Mulsa hitam perak juga dapat mempercepat umur panen,sehingga tanaman dapat dipanen lebih cepat dan hasilnya lebih melimpah.

\section{Panjang Polong}

Hasil analisia ragam menunjukan bahwa bahwa tidak terjadi interaksi antara kombinasi perlakuan dosis pupuk bokashi dan macam jenis mulsa pada parameter panjang polong pada akumulasi panen pertama sampai ke lima.

\begin{tabular}{|c|c|}
\hline PENGARUH DOSIS PUPUK BOKASHI SAPI & MUHAMMAD ROFIQ, PAMUJI SETYO UTOMO \\
\hline PENGGUNAAN & dan TARWA MUSTOFA \\
\hline \multicolumn{2}{|l|}{ TERHADAP PRODUKSI TANAMAN KACANG } \\
\hline $\begin{array}{l}\text { PANJANG (Vigna sinensis } \\
\text { PERTIWI }\end{array}$ & \\
\hline
\end{tabular}


Tabel 6. Rata-rata panjang polong tanaman kacang panjang akibat pengaruh pemberian dosis pupuk bokashi dan penggunaan jenis mulsa

\begin{tabular}{cc}
\hline Perlakuan & Rata - rata \\
\hline B1 & 75,21 \\
B2 & 73,61 \\
B3 & 73,32 \\
BNT 5\% & 11,5 \\
M1 & 74,59 \\
M2 & 71,5 \\
M3 & 76,06 \\
\hline
\end{tabular}

Keterangan: Nilai yang diikuti dengan huruf yang sama pada baris dan kolom yang sama, tidak berbeda nyata pengaruhnya pada uji BNT pada taraf $5 \%$.

Berdasarkan uji BNT 5\% menunjukan bahwa kombinasi pupuk bokashi dan macam jenis mulsa tidak berbeda nyata terhadap variabel panjang polong dari akumulasi panen pertama hingga ke lima.

Hal ini disebabkan tempat penelitian yang diapit oleh pepohonan di sekitar, sehingga menyebabkan tanaman kekurangan cahaya matahari untuk berfotosintesis. Sehingga produksi tanaman tidak optimal, karena tanaman ini memerlukan banyak sinar matahari. Dan faktor genetik benih kacang Panjang varietas pertiwi yang memang memiliki panjang polong antara $69 \mathrm{~cm}-82 \mathrm{~cm}$ (lampiran 2)

Menurut (Asripah, 2007) Keadaan iklim merupakan faktor yang harus di perhatikan, kacang panjang dapat tumbuh dengan baik di ketinggian kurang dari 600 mdpl. Temperatur yang dikehendaki berkisar antara $18-32^{\circ} \mathrm{C}$ dengan suhu optimal $25^{\circ} \mathrm{C}$. Tanaman ini membutuhkan banyak sinar matahari

Di dukung juga oleh Rukmana dalam penelitian Kharisma (2014), penggunaan mulsa plastik hitam perak jika suhu udara sudah mendekati optimal untuk mendukung pertumbuhan tanaman, maka fungsi mulsa plastik tidak berpengaruh nyata.

\section{PENUTUP}

\section{Kesimpulan}

1. Terjadi interaksi pada variabel panjang tanaman umur $42 \mathrm{hst}$, dan terjadi interaksi nyata pada varisabel diameter batang umur 28 dan 42 hst.

2. Terjadi perbedaan pada perlakuan tunggal, yaitu perlakuan mulsa pada variabel jumlah helai daun pada umur 14, 28, dan 42 hst.

3. Tidak terjadi interaksi pada variabel berat polong, jumlah polong, dan panjang polong pada akumulasi panen I - V. Akan tetapi ada perbedaan nyata pada perlakuan tunggal, yaitu perlakuan mulsa pada variable berat dan jumlah polong per tanaman pada akumulasi panen I-V. 


\section{Saran}

1. Disarankan untuk melakukan penelitian lanjutan tentang dosis pupuk bokashi dengan meningkatkan dosis hingga level optimum, karena dimungkinkan masih dapat meningkatkan hasil tanaman kacang panjang (vigna sinensis L.).

2. Disarankan untuk melakukan penelitian lanjut tentang penggunaan macam mulsa, karena masih banyak jenis mulsa yang mungkin dapat meningkatkan hasil produksi ntanaman kacang panjang (vigna sinensis L.).

\section{DAFTAR PUSTAKA}

Asripah. (2007). Budidaya Kacang Panjang. Azka Press:Jakarta. 13-17 hal.

Erika T., Lilik S. dan Agus S. (2013).Penggunaan Beberapa Jenis Mulsa terhadap Produksi Baby Wortel (Daucus Carota L.) Varietas Hibrida. Fakultas Pertanian. Universitas Brawijaya

Haryanto, E., Suhartini T. dan Rahayu E. (2007). Budidaya Kacang Panjang. Penebar Swadaya. Jakarta.

Hutapea, J.R. (1994). Inventaris Tanaman Obat Indonesia III, Badan Penelitian dan Pengembangan Kesehatan. Jakarta.

Kharisma M. Prayoga, Moch. Dawam M. dan Agus S. (2014). Kajian Penggunaan

Mulsa Plastik dan Tiga Generasi Umbi Bibit yang Berbeda pada Komoditas

Kentang (Solanum tuberosum L.) Varietas Granola. Jurusan Budidaya Pertanian.

Fakultas Pertanian. Universitas Brawijaya

Lingga dan Marsono. (2006). Petunjuk Penggunaan Pupuk. Penebar Swadaya: Jakarta. 